\title{
Implementasi Sistem Informasi Manajemen (SIM) Dalam Meningkatkan Mutu Proses Pembelajaran
}

\author{
Imam Hambali ${ }^{1}$ \\ ${ }^{1}$ (Pendidikan Agama Islam, Institut Agama Islam (IAI) Al-Azhaar Lubuklinggau, Indonesia). \\ * Corresponding Author. E-mail: 1imamhambali1873@yahoo.com
}

\begin{tabular}{|l|l|l|}
\hline Receive: 19/01/2021 & Accepted: 28/02/2021 & Published: 04/03/2021 \\
\hline
\end{tabular}

\begin{abstract}
Abstrak
Penelitian ini adalah untuk mengetahui perencanaan, pelaksanaan, evaluasi, dan hambatan implementasi sistem informasi manajemen dalam meningkatkan mutu proses pembelajaran. Penelitian ini dengan menggunakan pendekatan kualitatif yakni metode penelitian yang digunakan untuk meneliti pada kondisi obyek yang alamiah dimana peneliti adalah sebagai instrumen kunci. Teknik pengumpulan data yang digunakan adalah observasi, wawancara, dan dokumentasi.Data dianalisis menggunakan reduksi data, peyajian data, dan penarikan kesimpulan. Hasil penelitian ini menunjukkan bahwa a) Proses perencanaan peningkatan mutu proses pembelajaran dengan pemanfaatan sistem informasi manajemen adalah: 1) Merinci secara cermat dan menganalisis secara sistematis terhadap tujuan yang hendak dicapai, 2) Mencari alternatif yang relevan, 3) Menggambarkan biaya total, dan 4) Membandingkan dan menganilis alternative. b) Pelaksanaan peningkatan mutu proses pembelajaran dengan pemanfaatan sistem informasi manajemen pada dua sekolah tersebut, diterapkan dalam kurikulum melalui :1) program pengembangan diri, 2) pengintegrasian ke dalam semua mata pelajaran, dan 3) pembiasaan. c) Evaluasi peningkatan Mutu Proses Pembelajaran dengan Pemanfaatan Sistem Informasi Manajemen yaitu dengan penyebaran angket/kuisioner kepada seluruh siswa sebagai sasaran utama peningkatan mutu tersebut. Evaluasi peningkatan mutu pembelajaran dilaksanakan pada tengah semester dan akhir semester gasal. d) Hambatan dalam peningkatan mutu pembelajaran dengan pemanfaatan system informasi manajemen di Sekolah, secara umum terkait hambatan secara psikologis, secara administrative, hambatan secara administratif, hambatan dari segi anggaran, dan hambatan pada Sumber daya manusia yang berimplikasi secara umum terhadap ketercapaian tujuan penyelenggaraan pendidikan.
\end{abstract}

Kata Kunci: Mutu, Pembelajaran, SIM

Abstract

This study is to determine the planning, implementation, evaluation, and barriers to the implementation of management information systems in improving the quality of the learning process. This study uses a qualitative approach, namely the research method used to examine the natural conditions of the object where the researcher is the key instrument. Data collection techniques used were observation, interviews, and documentation. Data were analyzed using data reduction, data presentation, and drawing conclusions. The results of this study indicate that a) The planning process for improving the quality of the learning process with the use of management information systems is: 1) Detailed detailing and systematic analysis of the objectives to be achieved, 2) Searching for relevant alternatives, 3) Describing the total cost, and 4 ) Comparing and analyzing alternatives. b) Implementation of improving the quality of the learning process by utilizing management information systems in the two schools, implemented in the curriculum through: 1) selfdevelopment programs, 2) integration into all subjects, and 3) habituation. c) Evaluation of the improvement of the Quality of the Learning Process with the Utilization of Management Information Systems, namely by distributing questionnaires to all students as the main target of the quality improvement. Evaluation of improving the quality of learning is carried out in the middle of the semester and the end of the odd semester. d) Barriers to improving the quality of learning through the use of management information systems in schools, in general, are related to psychological, administrative, administrative barriers, budgetary constraints, and obstacles to human resources which have general implications for the achievement of the objectives of education.

Keywords: Quality, Learning, SIM 


\section{Pendahuluan}

Perkembangan masyarakat selalu harus memperhatikan dua sumber utama yaitu, Sumber Daya Alam (Natural Resources Potensial) dan Sumber Daya Manusia (Human resources Potensial). Menurut Ngalim Purwanto dalam (Sofyan, 2020) yang mengemukakan bahwa "Pengembangan sumber daya manusia adalah bidang kebudayaan, dimana pendidikan merupakan bagian yang penting di dalamnya".

Pendidikan adalah investasi sumber daya manusia terbesar yang memiliki nilai strategis bagi kelangsungan peradaban manusia di dunia.Sejarah telah membuktikan bahwa kemajuan dan kejayaan suatu bangsa di dunia ditentukan oleh pembangunan di bidang pendidikan.Pendiri Negara Indonesia menempatkan pendidikan sebagai sesuatu yang penting dan utama.Hal ini dapat dilihat dari isi Pembukaan Undang-undang Dasar 1945 alinea IV yang menegaskan bahwa salah satu tujuan bangsa Indonesia adalah mencerdaskan kehidupan bangsa.

Pendidikan masa depan adalah pendidikan yang tanggap terhadap tantangan persaingan dan kerja sama global. Sistem Pendidikan Nasional dituntut untuk melakukan perubahan dan penyesuaian sehingga dapat mewujudkan proses pendidikan yang lebih demokratis, memperhatikan keberagaman kebutuhan/ keadaan daerah dan peserta didik, serta mendorong peningkatan partisipasi masyarakat.

Dengan demikian, konsekwensi pemberian kewenangan yang lebih besar kepada sekolah membawa perubahan terhadap manajemen sekolah. Alasan untuk merestruksikan manajemen sekolah menurut Dadang Dally dalam (Hendar, 2020) antara lain: efesiensi dalam administrasi pendidikan umum, efek resesi ekonomi, kompleksitas permasalahan pendidikan, pemberdayaan guru dan orangtua, keperluan akan adanya fleksibilitas dan sifat responsif sekolah, efektivitas sekolah dan meningkatkan kinerja.

Sekolah atau lembaga pendidikan tentunya tak bisa lari dari yang namanya manajemen. menurut (Tanjung, 2020)Layaknya sebuah perusahaan, sekolah atau lembaga pendidikan mempunyai pimpinan, karyawan, pelanggan, serta produk yang dijual atau dihasilkan. Tentunya semua itu memerlukan manajemen yang baik, terarah, dan terencana. Sehingga tidak akan timbul kemunduran atau bahkan berhentinya pengoperasian perusahan tersebut, yang dalam hal ini adalah sekolah.

Dewasa ini, teknologi informasi berkembang pesat.Hal itu ternyata juga berdampak pada manajemen perusahaan tak terkecuali sekolah.Banyak sekolah yang sudah memanfaatkan teknologi informasi dalam manajemennya.Sehingga sekarang ini banyak sekolah yang sudah menerapkan Sistem Informasi Manajemen dalam lembaganya.

Menurut bahwa (Arifudin, 2018) suatu lembaga pendidikan formal memiliki keinginan untuk menjelaskan, mendefinisikan serta menerapkan suatu model pendidikan yang berdasarkan ekspektasinya memilki kapabilitas dan sesuai dengan perkembangan zaman.

Manajemen pendidikan pada era informasi merupakan suatu prioritas untuk kelangsungan pendidikan atau dengan kata lain merupakan suatu bentuk pendidikan yang harus memiliki ciri khusus untuk menciptakan hasil yang sesuai dengan tujuan lembaga pendidikan. $\mathrm{Hal}$ ini disebabkan penurunan perkembangan pendidikan dilihat dari segi kualitas dan hasil dari ekspektasi lembaga pendidikan.Selain itu, penurunan ini juga 
disebabkan oleh tidak tersedianya manajemen yang baik untuk mengelola pendidikan di beberapa lembaga pendidikan.

Pendidikan harus menetapkan visi dan misi yang jelas untuk memproduksi keputusan yang berkualitas dan beroperasi secara maksimal seiring perkembangan zaman.Untuk mewujudkan hal ini, perlu dibuat suatu struktur dan manajemen yang pasti dan sesuai dengan visi dan misi lembaga pendidikan.Melalui penggunaan internet dan sistem informasi, lembaga pendidikan dapat mengembangkan manajemen yang baik.

Undang-undang Sisdiknas No. 20 Tahun 2003 menyatakan bahwa Pendidikan adalah usaha sadar dan terencana untuk mewujudkan suasana belajar dan proses pembelajaran agar peserta didik secara aktif mengembangkan potensi dirinya untuk memiliki kekuatan spiritual keagamaan, pengendalian diri, kepribadian, kecerdasan, akhlak mulia, serta keterampilan yang diperlukan dirinya, masyarakat, bangsa dan negara.

Pendidikan nasional bertujuan untuk mengembangkan segala potensi peserta didik agar menjadi manusia yang beriman dan bertaqwa kepada Tuhan yang Maha esa, berakhlak mulia, sehat, berilmu, cakap, kreatif, mandiri dan menjadi warga negara yang demokratis serta tanggungjawab. Berdasarkan fungsi dan tujuan pendidikan nasional tersebut,jelas bahwa pendidikan harus diselenggarakan secara sistematis guna mencapai tujuan tersebut. Pendidikan pada dasarnya adalah proses komunikasi yang di dalamnya berisi suatu transformasi pengetahuan, berbagai nilai dan keterampilan baik di dalam maupun luar sekolah yang berlangsung secara konstan dari satu generasi ke generasi berikutnya.

Dalam perkembangannya teknologi informasi dan komunikasi telah berhasil membuka kemungkinan-kemungkinan kegiatan yang sebelumnya sulit atau bahkan tidak dapat dilakukan, namun saat ini dengan mudah bisa dilakukan, contohnya kegiatan berbagi informasi penerimaan murid baru yang biasanya pakai spanduk namun sekarang melalui IT dapat diketahui semua orang dan juga kegiatan berkirim informasi ataupun kegiatan-kegiatan pendidikan secara online. Dan terkait penerapan sistem informasi manajemen beserta komponen infra struktur dari teknologi informasi dan komunikasi benar-benar telah menandai terjadinya revolusi peradaban yang memungkinkan pekerjaan-pekerjaan dalam sistem organisasi dapat diselesaikan dengan cepat, akurat, efektif dan efisien.

Menurut (Ahmad, 2013)menegaskan bahwa Pendidikan di era globalisasi saat ini memiliki identitas yang ditandai dengan perkembangan teknologi informasi dan komunikasi menuntut adanya penyempurnaan sistem pendidikan, misalnya penyempurnaan pada manajemen pendidikan yang modern dan professional dengan bernuansa pendidikan. Di sisi lain kemajuan ilmu dan teknologi informasi telah banyak mengubah cara pandang dan gaya hidup masyarakat Indonesia dalam menjalankan kegiatannya. Keberadaan dan peranan teknologi informasi dalam sistem pendidikan telah membawa era baru dalam perkembangan dunia pendidikan kita, tetapi perkembangan tersebut belum diimbangi dengan peningkatan sumber daya manusia yang menentukan keberhasilan dunia pendidikan Indonesia pada umumnya. Hal ini lebih disebabkan masih tertinggalnya sumber daya manusia kita untuk memanfaatkan teknologi informasi dalam proses pendidikan tersebut.

Konsep pembelajaran menurut Corey dalam (Tanjung, 2019)adalah "suatu proses dimana lingkungan seseorang secara disengaja dikelola untuk memungkinkan ia 
turut serta dalam tingkah laku tertentu dalam kondisi-kondisi khusus atau menghasilkan respons terhadap situasi tertentu, pembelajaran merupakan subset khusus dari pendidikan".

Pengelolaan sistem informasi manajemen pendidikan dapat digunakan dalam penyelenggaran proses pendidikan, sebagai upaya meningkatkan mutu pembelajaran. Sistem informasi manajemen dapat menunjang dalam perbaikan mutu pembelajaran sehingga tujuan pendidikan dapat tercapai yakni menghasilkan mutu lulusan.

Dalam dunia pendidikan pengelolaan dan penggunaan sistem informasi manajemen pendidikan tidak dapat dipisahkan dari aktivitas pendidikan itu sendiri dimana itu terkait proses belajar mengajar maupun dari awal siswa dan guru itu masuk kedalam sekolah dan keluar juga dari sekolah itu. Meningkatnya ilmu pengetahuan dan teknologi terutama dalam bidang komputerisasi telah menunjukkan bahwa perkembangan tersebut dapat membantu menyelesaikan suatu masalah pada proses penerapan sistem informasi manajemen pendidikan. Dan dengan pemanfaatan teknologi informasi manajemen ini juga akan dapat mengurangi tahap proses kerja dalam organisasi, pemanfaatan dan perkembangan inilah yang nantinya akan dapat membantu setiap pihak-pihak terkait yang dilakukan dalam suatu organisasi maupun masyarakat sekolah.

Menurut (Zulkifli, 2001) menegaskan bahwa "Informasi sendiri merupakan sebuah data yang sudah dibentuk atau dimanipulasi sesuai dengan keperluan tertentu, sedangkan data adalah fakta yang sudah ditulis dalam bentuk catatan atau direkam ke dalam berbagai bentuk media (komputer misalnya)". Informasi juga diartikan sebagai data yang telah disusun sedemikian rupa sehingga bermakna dan bermanfaat karena dapat dikomunikasikan kepada seseorang yang akan menggunakan untuk membuat keputusannya.

Menurut Sabandi dalam (Juhji, 2020) bahwa "salah satu pemanfaatan sistem informasi manajemen yang bisa diaplikasikan di organisasi adalah sistem informasi manajemen kepegawaian". Hal ini tentu saja memiliki suatu tujuan untuk dapat memudahkan pekerjaan setiap pemimpin maupun pegawai dalam mendapatkan informasi terkait semua hal yang berhubungan dengan pegawai.Sistem informasi manajemen kepegawaian merupakan sebuah sistem untuk menangangi berbagai hal yang berkaitan dengan pengurusan kepegawaian, sehingga dapat memudahkan pegawai negeri sipil untuk meningkatkan kebutuhan administrasi kepegawaian.

Dalam rangka menunjang tercapainya sasaran dan tujuan fungsifungsi operasional dalam organisasi pendidikan. Dengan adanya sistem informasi manajemen lembaga pendidikan akan merasakan beberapa manfaat sebagai berikut, pertama, tersedianya sistem pengelolaan data dan informasi pendidikan. Kedua, terintegrasinya data dan informasi pendidikan untuk mendukung proses pengambilan keputusan. Ketiga, tersedianya data dan informasi pendidikan yang lengkap bagi seluruh stakeholders yang berkepentingan dalam bidang pendidikan.

Optimalisasi sumber-sumber daya berkenaan dengan pemberdayaan sekolah merupakan alternatif yang paling tepat untuk mewujudkan suatu sekolah yang mandiri dan memiliki keunggulan tinggi.Pemberdayaan dimaksudkan untuk memberikan otonomi yang lebih luas untuk memecahkan masalah di sekolah. Hal itu menurut (Fattah, 2004) bahwa "diperlukan suatu perubahan kebijakan dibidang manajemen pendidikan dengan prinsip memberikan kewenangan dalam pengelolaan dan pengembilan keputusan 
sesuai dengan tuntutan dan kebutuhan masing-masing sekolah secara lokal".

Sistem informasi manajemen secara khusus dirancang untuk memenuhi kebutuhan Sekolah atau lembaga pendidikan lainnya yang menginginkan layanan pendidikan yang terkomputerisasi untuk meningkatkan kinerja, kualitas pelayanan, daya saing dan kualitas SDM yang dihasilkannya.Teknologi Informasi berperan penting dalam memperbaiki kinerja suatu organisasi. Penggunaannya tidak hanya sebagai proses otomatisasi terhadap akses informasi, tetapi juga menciptakan akurasi, kecepatan, dan kelengkapan sebuah sistem yang terintegrasi sehingga proses organisasi yang terjadi akan efisien, terukur, fleksibel. Pemanfaatan teknologi informasi menjadi kebutuhan yang tak dapat ditawar lagi, karena ketersediaan informasi yang terintegrasi makin penting dalam mendukung upaya menciptakan sistem perusahaan/organisasi yang efisien dan kompetitif.

Sistem informasi manajemen sangat membantu dalam pengelolaan data nilai siswa/mahasiswa, mata pelajaran/kuliah, data staf pengajar (guru/dosen) serta administrasi fakultas/jurusan yang sifatnya masih manual untuk dikerjakan dengan bantuan Software agar mampu mengefektifkan waktu dan menekan biaya operasional. Sistem informasi manajemen memberikan kemudahan dalam mengelola Proses Pembelajaran, Data Guru, Data Siswa, Data Mata Pelajaran, dan Data Nilai Siswa.

Sistem informasi manajemen dikembangkan secara aktif dan kontinu.Setiap pengguna Sistem informasi manajemen berhak memberikan masukanmasukan positif berdasarkan kebutuhan mereka.

Berbagai permasalahan yang ada dalam dunia pendidikan saat ini telah mampu diatasi dengan pemanfaatan jaringan komputer yang mampu menyajikan fasilitas komunikasi, pertukaran data maupun informasi yang cepat dan akurat, dan membuat jarak diantara pemakai menjadi tidak penting. Dengan keberadaan jaringan pemakai dapat berbicara dalam bentuk text dan audio visual, variasi fasilitas yang dapat diberikan oleh suatu jaringan sangat tergantung pada jenis dan versi aplikasi yang digunakan dan tentu harus didukung dengan kondisi hardware yang memadai sebagai suatu prasyarat dalam penggunaan software aplikasi.

Sistem informasi manajemen merupakan solusi yang paling banyak digunakan dalam mengelola data-data akademik lembaga pendidikan yang ada di Indonesia. Selain mempermudah proses pengelolaan data, sistem informasi ini juga memperkecil biaya operasional yang harus dikeluarkan oleh lembaga terkait. Hal ini sangat sesuai dengan kondisi perekonomian negara yang tidak menentu sekarang ini. Seperti telah dijelaskan pada bab sebelumnya, penggunaan sistem informasi manajemen itu sendiri dapat dijadikan sarana yang sangat menguntungkan bagi peserta didik yang tidak mungkin mengikuti proses akademis secara langsung, seperti melakukan proses registrasi, atau proses belajar mengajar di kelas.

Sesungguhnya sistem informasi makanan tidak bertujuan untuk menggeser sistem konvensional yang sudah ada sebelumnya. Bagaimanapun juga proses lama tersebut masih perlu digunakan dalam beberapa proses pembelajaran seperti tatap muka antara siswa dengan pengajarnya. Menurut Riyana dalam (Arifudin, 2019), sebagai bagian dari pembelajaran, teknologi informasi memiliki tiga kedudukan, yaitu sebagai suplemen, komplemen, dan substitusi. Peserta didik tidak memiliki kewajiban untuk mengakses materi pembelajaran melalui teknologi 
informasi sehingga disebut sebagai suplemen. Namun peserta didik yang memanfaatkannya tentu akan memiliki tambahan pengetahuan atau wawasan.

Teknologi informasi dikatakan berfungsi sebagai komplemen atau pelengkap bila materi pembelajaran pada sistem informasi diprogramkan untuk melengkapi materi pembelajaran yang diterima peserta didik di dalam kelas. Sehubungan dengan hal ini, ada 3 alternatif model kegiatan pembelajaran yang dapat dipilih para mahasiswa, yaitu apakah mereka akan mengikuti kegiatan pembelajaran yang disajikan secara konvensional saja, atau sebagian secara tatap muka dan sebagian lagi melalui internet, atau bahkan sepenuhnya melalui internet. Alternatif model pembelajaran manapun yang akan dipilih oleh para mahasiswa tidak menjadi masalah dalam penilaian. Keadaan yang sangat fleksibel ini dinilai sangat membantu para mahasiswa untuk mempercepat penyelesaian perkuliahannya.

Hingga saat ini telah dikembangkan sistem informasi akademis dalam berbagai bentuk.Mulai dari sistem informasi yang dapat diakses melalui internet, intranet maupun sms. Aplikasi yang dikembangkan juga memiliki fungsi antara lain untuk melihat nilai, mengambil bahan kuliah, kuliah online, hingga proses registrasi yang semuanya bisa dilakukan melalui internet, sms, maupun koneksi yang lain. Manfaat dari penggunaan sistem informasi manajemen juga bermacam-macam. Mulai dari penanganan masalah administrasi pada saat penerimaan mahasiswa baru, pengelolaan data akademik mahasiswa, pelaksanaan kegiatan perkuliahan, manajemen sumber daya serta proses pengambilan kebijakan dari eksekutif yang semuanya dapat dilakukan secara lebih efektif dan optimal dengan menggunakan sistem informasi.
Sedangkan Menurut Karsidi dalam (Nadeak, 2020) bahwa "masalah pokok yang dihadapi pendidikan di Indonesia antara lain mengenai peningkatan mutu, pemerataan kesempatan pendidikan, dan relevansi pendidikan dengan pembangunan nasional". Masalah tersebut membutuhkan penyelesaian selain cara konvensional yang dikenal selama ini. Secara umum aplikasi sistem informasi dalam pendidikan diharapkan mampu melakukan hal-hal sebagai berikut : 1) Dapat menyebarkan informasi secara luas, seragam dan cepat, 2) Dapat membantu, melengkapi dan menggantikan tugas guru bila diperlukan, 3) Dapat menunjang kegiatan belajar masyarakat serta mengajak partisipasi masyarakat, 4) Dapat menambah keanekaragaman sumber maupun kesempatan belajar, 5) Dapat menambah daya tarik untuk belajar, dan 6) Dapat menghemat biaya.

Semula teknologi pendidikan dipandang hanya berperan pada taraf pelaksanaan kurikulum di kelas. Sementara konsepsi baru yang akan digunakan menghendaki teknologi pendidikan sebagai masukan (input) bahkan sejak tahap perencanaan kurikulum. Dengan demikian bentuk teknologi pendidikan yang akan diterapkan sudah harus dikaji sejak perencanaan kurikulum.

Pemilihan teknologi dalam pendidikan akan membuka kemungkinan untuk lahirnya berbagai alternatif bentuk kelembagaan baru yang menyediakan fasilitas belajar. Serangkaian kriteria pemanfaatan teknologi dalam pendidikan, antara lain: harus dijaga kesesuaiannya (kompatibilitas) dengan sarana dan teknologi yang sudah ada, dapat menstimulasikan perkembangan teknologi dan ilmu pengetahuan, serta mampu memacu usaha peningkatan mutu pendidikan itu sendiri. Dengan demikian, adanya penerapan suatu teknologi dalam pendidikan akan sangat mungkin terjadi 
perubahan besar-besaran dalam interaksi belajar mengajar antara sumbersumber belajar dengan pelaku belajar.

Pendidikan memegang peranan vital dalam mengembangkan dan meningkatkan kualitas sumber daya manusia.Akan tetapi, minat dan perhatian pada aspek kualitas jasa pendidikan bisa dikatakan baru berkembang dalam satu dekade terakhir.Keberhasilan jasa pendidikan ditentukan dalam memberikan pelayanan yang berkualitas kepada para pengguna jasa pendidikan tersebut.

Dalam studi awal di beberapa Sekolah Menengah Kejuruan yang menjadi tempat penelitian, implementasi system informasi manajemen belum dilakukan secara komprehensif dalam seluruh aktifitas pengelolaan Sekolah.Sehingga belum dapat menyentuh pada tujuan pendidikan yaitu menghasilkan lulusan yang bermutu.Indikator yang ada adalah dilihat dari prestasi akademik peserta didik.Hal ini yang menjadi dasar pertimbangan sangat pentingnya melakukan penelitian lanjutan dalam judul "Implementasi Sistem Informasi Manajemen Dalam Meningkatkan Mutu Proses Pembelajaran".

\section{Metode}

Metode penelitian iniimplementasi sistem informasi manajemen dalam meningkatkan mutu proses pembelajaran menggunakan metode kualititaif deskriptif analisis, yang dilakukan dengan cara mendeskripsikan fakta-fakta yang kemudian disusul dengan analisis. Sebagai sumber data, yaitu berbagai referensi atau sumber pustaka tentang kajian implementasi sistem informasi manajemen dalam meningkatkan mutu proses pembelajaran. Adapun Teknik pengumpulan data melalui teknik dokumentasi, yaitu dengan cara-cara membaca secara cermat dan kritis terhadap berbagai referensi. Setelah membaca, kemudian mencatat data-data yang menunjukkan keterhubungan dengan tujuan penelitian ini. Adapun teknik analisis data menggunakan model Miles dan Huberman (Sugiyono, 2015). Demi terjaga keakuratan data, keabsahan data (trustwortines) diperiksa melalui triangulasi penyidik.

\section{Hasil dan Pembahasan}

Berdasarkan hasil penelitian bahwa implementasi peningkatan mutu pembelajaran dengan pemanfaatan system informasi manajemen belum optimal dilakukan sesuai tahapan manajemen pendidikan. Sekolah belum mampu mengoptimalkan fungsi-fungsi manajemen pendidikan dalam proses pembelajaran dengan pemanfaatan system informasi manajemen yang mencakup perencanaan, pelaksanaan dan evaluasi.

Kaitan dengan hal ini menurut Syafaruddin dalam (Sudirman, 2020) bahwa manajemen adalah "kemampuan mengarahkan dan mencapai hasil yang diinginkan dengan pemberdayaan manusia dan sumber daya lainnya". Kemudian menurut Ricky W. Griffin dalam (Damayanti, 2020) mendefinisikan manajemen sebagai suatu rangkaian aktifitas (termasuk perencanaan, dan pengambilan keputusan, pengorganisasian, kepemimpinan, dan pengendalian) yang diarahkan pada sumber- sumber daya organisasi (manusia, finansial, fisik, dan informasi) dengan maksud untuk mencapai tujuan organisasi secara efektif dan efisien. Hal ini sejalan dengan penelitian (Mustiningsih, 2020)yang menjelaskan bahwa Program keterampilan MA dilaksanakan dengan menggunakan sistem moving class, sehingga pada jam yang sudah dijadwalkan, anak-anak dari kelas yang berbeda namun memilih jurusan keterampilan yang sama akan bergerak menuju laboratorium keterampilan sesuai dengan jurusannya. Model dari 
pelaksanaan program keterampilan di madrasah masuk ke dalam kurikulum atau masuk kegiatan intrakurikuler.

Pendapat di atas menjelaskan, bahawa manajemen merupakan sebuah kemampuan dalam mengarahkan dan mencapai tujuan dengan memberdayakan sumber daya manusia melalui proses yang terdiri dari tahapan-tahapan dimulai dari perencanaan, pengorganisasian, pengarahan, dan pengawasan. Dalam manajemen terkandung pula pemanfaatan sumber daya yang ada untuk mencapai tujuan pendidikan atau sekolah sesuai visi dan misi sekolah.Sehingga fungsi manajemen dan sumber daya manusia terlibat dalam upaya mencapai tujuan sebuah organisasi.

Sumber daya yang terkandung dalam manajemen, yaitu manusia, bahan, sarana dan prasarana, metode, pembiaayaan, dan informasi. Sumber daya bersifat terbatas, sehingga tugas manajer dalam hal ini kepala sekolah harus dapat mengelola keterbatasan sumber daya tersebut secara efektif dan efisien untu mencapai sasarannya, baik tujuan programnya maupun organisasi secara umum.

Perencanaan yang dibuat sekolah dituangkan dalam RKS, berdasarkan tahapan Tujuan perencanaan, Materi perencanaan, Proses perencanaan, Keterlibatan semua pihak dalam perencanaan dan Perencanaan anggaran.Penyusunannya dilaksanakan awal tahun pelajaran dengan melibatkan semua stakeholder yang terkait.Sedangkan unsur-unsur yang terlibat dalam penyusunan RKS tersebut, yaitu kepala sekolah, wakasek kurikulum, guru, tenaga kependidikan, komite sekolah serta peserta didik yang diwakili OSIS.

Perencanaan pelaksanaan kegiatan implementasi peningkatan mutu proses pembelajaran dengan pemanfaatan system informasi manajemen dilakukan melalui beberapa strategi. Strategi penyusunan perencanaan mengacu kepada visi, misi dan tujuan masing-masing sekolah. Selain itu kebijakan penyusunan program kegiatan implementasi peningkatan mutu proses pembelajaran dengan pemanfaatan system informasi manajemen berdasarkan atas fenomena dan fakta di lingkungan sekolah maupun masyarakat menunjukan bahwa kegiatan implementasi peningkatan mutu proses pembelajaran dengan pemanfaatan system informasi manajemen sudah optimal sesuai dengan tujuan pemanfaatan system informasi manajemen.

Adapun yang menjadi dasar dalam penyusunan program kerja sekolah, yaitu visi, misi dan tujuan sekolah serta peraturan perundang-undangan yang terkait dengan implementasi peningkatan mutu proses pembelajaran dengan pemanfaatan system informasi manajemen. Sedangan penyusunan program kerja implementasi peningkatan mutu proses pembelajaran dengan pemanfaatan system informasi manajemen dengan berlandaskan kepada peraturan perundang-undangan yang terkait yang mengatur semua kegiatan pembelajaran.

Menurut Dauglass dalam (Arifudin, 2021) yang merumuskan lima prinsif manajemen pendidikan, diantaranya sebagai berikut :

a. Memprioritaskan tujuan di atas kepentingan pribadi dan kepentingan mekanisme kerja,

b. Mengkoordinasikan wewenang dan tanggung jawab,

c. Memberi tanggung jawab kepada personil hendaknya sesuai dengan sifatsifat dan kemampuannya,

d. Mengenal secara baik faktor-faktor psikologis manusia,

e. Memperhatikan nilai-nilai dalam organisasi.

Pendapat di atas dapat dijadikan acuan dalam penyusunan rencana program sekolah untuk mencapai tujuannya. Hal 
tersebut berdasarkan asumsi bahwa manajemen pendidikan merupakan proses penggunaan sumber daya (baik sumber daya manusia maupun non manusia) secara efektif dan efisien untuk mencapai tujuan pendidikan melalui fungsi perencanaan, pengorganisasian, pelaksanaan, serta pengawasan. Dalam pengelolaan pendidikan, menurut Rohiat dalam (Arifudin, 2020) terdapat 7 (tujuh) garapan manajemen yaitu :

a. Manajemen kurikulum

b. Manajemen kesiswaan

c. Manajemen personil/anggota

d. Manajemen sarana dan prasarana

e. Manajemen keuangan

f. Manajemen hubungan sekolah dan masyarakat, dan

g. Manajemen layanan khusus

Begitu pula dengan implementasi peningkatan mutu proses pembelajaran dengan pemanfaatan system informasi manajemen pada tingkat satuan pendidikan (SMK) harus memperhatikan semua unsur manajemen tersebut. Secara khusus, (Mulyasa, 2002) mengemukakan bahwa, upaya peningkatan kualitas pendidikan harus dimulai dengan pembenahan sekolah, disamping peningkatan mutu kualitas guru dan pengembangan sumber belajar".

Selanjutnya menurut (Kumorotomo, 2009)bahwa tujuan dibentuknya sistem informasi manajemen adalah supaya organisasi memiliki suatu sistem yang dapat diandalkan dalam mengolah data menjadi informasi yang bermanfaat dalam pembuatan keputusan manajemen, baik yang menyangkut keputusan-keputusan rutin maupun keputusan-keputusan strategik. Dengan demikian Sistem Informasi Manajemen adalah suatu sistem yang menyediakan kepada pengelola organisasi data maupun informasi yang berkaitan dengan pelaksanaan tugas-tugas organisasi
Oleh karena itu, dalam pelaksanaan implementasi peningkatan mutu proses pembelajaran dengan pemanfaatan system informasi manajemen, kepala sekolah memiliki peran penting sebagai manajer dalam menentukan arah keberhasilan, baik dalam mencapai tujuan organisasi secara khusus maupun tujuan pendidikan nasional secara umumnya, termasuk pelaksanaan implementasi peningkatan mutu proses pembelajaran dengan pemanfaatan system informasi manajemen.

Agar pelaksanaan implementasi peningkatan mutu proses pembelajaran dengan pemanfaatan system informasi manajemen tersebut mencapai tujuan sesuai rencana program yang telah dirumuskan sekolah, maka manajemen terpadu sekolah harus memfokuskan pada peningkatan kualitasnya. Kualitas yang dimaksud adalah sekolah sebagai lembaga pendidikan dalam pengelolaanya dapat memberikan layanan yang maksimal dan menjadikan peserta didiknya sebagai lulusan sesuai dengan tujuan pendidikan.

Hal ini memiliki relevansi dengan pendapat Ali dalam (Juhadi, 2020)yang mengemukakan Manajemen mutu itu sendiri pada hakekatnya menggambarkan kepada semua aktivitas dari fungsi manajemen secara keseluruhan, mulai dari perencanaan, pengorganisasian, pengendalian hingga kepemimpinan, yang menentukan kebijakan mutu, tujuan dan tanggung jawab serta implementasinya melalui alat-alat manajemen, seperti perencanaan, pengendalian, penjaminan dan peningkatan mutu.

Dengan demikian bahwa manajemen mutu sekolah merupakan segala aktivitas sekolah dengan menjalankan semua fungsifungsi manajemen secara sistemik yang dimulai dari tahapan perencanaan, pengorganisasian, pelaksanaan dan pengendalian dalam mencapai visi dan misi yang telah ditentukan. Adapun indikator- 
indikator menurut (Mulyasa, 2002)adalah sebagai berikut :

a. Indikator input: indikator ini meliputi karakteristik guru, fasilitas, perlengkapan, dan materi pendidikan serta kapasitas manajemen

b. Indikator process: indikator ini meliputi perilaku administratif, alokasi waktu guru dan alokasi waktu peserta didik

c. Indikator ouput: indikator dari output ini berupa hasil-hasil dalam bentuk perolehan peserta didik dan dinamikanya sistem sekolah, hasil yang berhubungan dengan prestasi belajar, dan hasil-hasil yang berhubungan dengan perubahan sikap, serta hasilhasil yang berhubungan dengan keadilan, dan keamanan

d. Indikator outcome: indikator ini meliputi jumlah lulusan ke tingkat pendidikan berikutnya, prestasi belajar di sekolah yang lebih tinggi dan pekerjaan serta pendapatan

Sedangkan berkaitan dengan pelaksanaan implementasi peningkatan mutu proses pembelajaran dengan pemanfaatan system informasi manajemen, (Rochaety, 2006)menjelaskan fungsi system informasi manajemen, beberapa kegunaan/fungsi Sistem Informasi antara lain sebagai berikut:

a. Meningkatkan aksesibilitas data yang tersaji secara tepat waktu dan akurat bagi para pemakai, tanpa mengharuskan adanya prantara sistem informasi

b. Menjamin tersediannya kualitas dan keterampilan dalam memanfaatkan sistem informasi secara kritis.

c. Mengembangkan proses perencanaan yang efektif

d. Mengidentifikasi kebutuhankebutuhan akan keterampilan pendukung sistem informasi

e. Menetapkan investasi yang akan diarahkan pada sistem informasi f. Mengantisipasi dan memahami konsekuensi-konsekuensi ekonomis dari sistem informasi dan teknologi baru

g. Memperbaiki produktivitas dalam aplikasi pengembangan dan pemeliharaan sistem

h. Organisasi menggunakan sistem informasi untuk mengolah transaksitransaksi, mengurangi biaya dan menghasilkan pendapatan sebagai salah satu produk atau pelayanan.

i. Bank menggunakan sistem informasi untuk mengolah cek-cek nasabah dan membuat berbagai laporan rekening koran dan transaksi yang terjadi.

j. Perusahaan menggunakan sistem informasi untuk mempertahankan persediaan pada tingkat paling rendah agar konsisten dengan dengan jenis barang yang tersedia.

k. Sitem informasi manajemen untuk pendukung pengambilan keputusan. I. Sistem informasi manajemen berdasarkan Aktivitas/Kegiatan manajemen.

I. Sistem informasi untuk pengendalian operasional.

m. Sistem informasi untuk pengendalian manajemen

n. Sistem informasi untuk perencanaan strategik.

o. Sistem informasi manajemen berdasarkan fungsi organisasi.

Selain dari itu, masyarakat dan orang tua mengharapkan anak-anaknya mendapatkan pendidikan yang bermutu agar mampu bersaing memperoleh berbagai keunggulan dan peluang di masa yang akan datang, baik dalam mencari pekerjaan, melajutkan ke perguruan tinggi maupun menginternalisasikan kehidupan berbasis teknologi informasi.

Pelaksanaan

implementasi peningkatan mutu proses pembelajaran dengan pemanfaatan system informasi manajemen diwujudkan sekolah melalui 
seluruh kegiatan-kegiatan yang ada di sekolah. Pelaksanaan implementasi peningkatan mutu proses pembelajaran dengan pemanfaatan system informasi manajemen disekolah termasuk dalam hal ini kegiatan belajar mengajar. Sistem informasi manajemen merupakan suatu badan yang memiliki bagian-bagian yang memiliki tugas-tugas tertentu. Menurut Made Pidarta dalam (Arifudin \& Damayanti, 2020) bahwa bagian-bagian itu adalah pengumpulan data, penyimpanan data, pemroses data, dan pemrogram data. Dalam bagian-bagian terdapat seseorang coordinator yang bertugas mengkordinir pada semua bagian Dan bertanggung jawab langsung pada manajemen puncak atau kepala sekolah.

Adapun masalah-masalah yang dihadapi sekolah, baik dari internal maupun eksternal merupakan suatu hal yang umum, termasuk dalam pelaksanaan implementasi peningkatan mutu proses pembelajaran dengan pemanfaatan system informasi manajemen. Namun demikian masalah-masalah yang menjadi hambatan dapat dijadikan pihak sekolah sebagai tantangan dan peluang untuk melakukan perbaikan-perbaikan ke depan. Upaya tersebut dalam rangka meminimalisir masalah yang muncul sebagai solusi positif kegiatan implementasi peningkatan mutu proses pembelajaran dengan pemanfaatan system informasi manajemen di sekolah. Pendekatan manajemen mutu harus menjadi komitmen sekolah sebagai penyelenggara pendidikan untuk semakin lebih baik memberi pelayanan.

\section{Simpulan}

Implementasi peningkatan mutu proses pembelajaran menggunakan sistem informasi manajemen dengan pendekatan manajemen pendidikan sudah menjalankan fungsi-fungsi dari manajemen yang meliputi perencanaan, pelaksanaan, dan evaluasi. Dalam menjalankan fungsi manajemen pendidikan tersebut, kepala sekolah sebagai manajer yang bertanggungjawab dalam peningkatan mutu proses pembelajaran dengan pemanfataan sistem informasi manajemen. Pelaksanaan peningkatan mutu proses pembelajaran dengan pemanfaatan system informasi manajemen diwujudkan oleh sekolah melalui seluruh penyelenggaraan akademik yang ada di sekolah. Hal ini berdampak kepada peningkatan mutu proses pembelajaran. Fakta di lapangan hal tersebut masih belum optimal dan hasilnya belum sesuai dengan yang diharapkan semua pihak.Hal ini di sebabkan adanya beberapa faktor yang di indikasikan sebagai penghambat, baik bersifat internal maupun eksternal.Sehingga SMK Bina Taruna dan SMK Bina Nusantara Subang terus berbenah diri dalam menyelenggarakan pembelajaran dengan pemanfataan sistem informasi manajemen.

\section{Daftar Pustaka}

[1] Sofyan, Y. (2020). Peranan Konseling Dosen Wali Dalam Meningkatkan Motivasi Belajar Mahasiswa Di Perguruan Tinggi Swasta Wilayah LLDIKTI IV. Jurnal Bimbingan Dan Konseling Islam, 10(2), 237-242.

[2] Hendar. (2020). Pengaruh Penilaian Diri Dan Efikasi Diri Terhadap Kepuasan Kerja Serta Implikasinya Terhadap Kinerja Guru. Jurnal IImiah MEA (Manajemen, Ekonomi, Dan Akuntansi), 4(1).

[3] Tanjung, R. (2020). Manajemen Pemasaran Pendidikan. Bandung: Widina Bhakti Persada.

[4] Arifudin, O. (2018). Pengaruh Pelatihan Dan Motivasi Terhadap Produktivitas Kerja Tenaga Kependidikan STIT Rakeyan Santang Karawang. MEA (Manajemen, Ekonomi, \& Akuntansi), 2(3), 209-218.

[5] Ahmad. (2013). Manajemen Pembelajaran. Yogyakarta : Deepublish. 
[6] Tanjung, R. (2019). Manajemen Pelayanan Prima Dalam Meningkatkan Kepuasan Mahasiswa Terhadap Layanan Pembelajaran (Studi Kasus di STIT Rakeyan Santang Karawang). Jurnal Ilmiah MEA (Manajemen, Ekonomi, \& Akuntansi), 3(1), 234-242.

[7] Zulkifli. (2001). Manajemen Sistem Informasi. Jakarta: PT. Gramedia Pustaka Utama.

[8] Juhji. (2020). Manajemen Humas Sekolah. Bandung: Widina Bhakti Persada.

[9] Fattah, N. (2004). Konsep Manajemen Berbasis Sekolah (MBS) dan Dewan Sekolah. Bandung: CV Pustaka Bani Quraisy.

[10] Arifudin, O. (2019). Manajemen Sistem Penjaminan Mutu Internal (SPMI) Sebagai Upaya Meningkatkan Mutu Perguruan Tinggi. MEA (Manajemen, Ekonomi, \& Akuntansi), 3(1), 161-169.

[11] Nadeak, B. (2020). Manajemen Humas Pada Lembaga Pendidikan. Bandung: Widina Bhakti Persada.

[12] Sugiyono. (2015). Metode Penelitian Pendidikan (Pendekatan Kuantitatif,. Kualitatif dan R\&D). Bandung: CV. Alfabeta.

[13] Sudirman, A. (2020). Prilaku konsumen dan perkembangannya di era digital. Bandung: Widina Bhakti Persada.

[14] Damayanti, F. (2020). Pengaruh Lingkungan Kerja Dan Karakteristik Individu Terhadap Kinerja Pegawai BANK BRI Syariah Kabupaten Subang. ISLAMIC BANKING: Jurnal Pemikiran Dan Pengembangan Perbankan Syariah, 6(1), 35-45.

[15] Mustiningsih. (2020). Manajemen Kemitraan Madrasah Aliyah Dengan Balai Latihan Kerja Dalam Program Keterampilan. JAMP: Jurnal Adminitrasi
Dan Manajemen Pendidikan., 3(3), 283298.

[16] Arifudin, O. (2021). MANAJEMEN STRATEGIK TEORI DAN IMPLEMENTASI. Banyumas : Pena Persada.

[17] Arifudin, O. (2020). Psikologi Pendidikan (Tinjauan Teori Dan Praktis). Bandung : Widina Bhakti Persada.

[18] Mulyasa. (2002). Manajemen Berbasis Sekolah, Konsep, Strategi, dan Implementasi. Bandung: PT. Remaja Rosdakarya.

[19] Kumorotomo. (2009). Sistem Informasi Manajemen. yogyakarta: Gadja Mada University Press.

[20] Juhadi. (2020). Pengaruh Sistem Pengendalian Internal Dan Audit Internal Terhadap Pelaksanaan Good Corporate Governance. Jemasi: Jurnal Ekonomi Manajemen Dan Akuntansi, 16(2), 17-32.

[21] Rochaety. (2006). Sistem Informasi Manajemen Pendidikan. Jakarta : Bumi Aksara.

[22] Arifudin \& Damayanti. (2020). PENGARUH PENEMPATAN KARYAWAN TERHADAP EFEKTIVITAS KERJA PADA PT AGRO BUMI. Value : Jurnal Manajemen Dan Akuntansi, 15(2), 14-21.

\section{Profil Penulis}

Imam Hambali.Penulis lahir di Bandung pada tanggal 8 Oktober 1988. Pendidikan tinggi penulis antara lain (a) Program Strata 1 dengan jurusanPendidikan Agama Islam STAI Ma`arif Jambilulus tahun 2011; (b) Program Strata 2Sekolah Tinggi IImu Administrasi Yapannlulus tahun 2013; (c) Program Strata 3Universitas Merdeka MalangLulus tahun 2019; Penulis merupakan Dosen Pascarsarjana Pendidikan Agama Islam di Institut Agama Islam (IAI) Al-Azhaar Lubuklinggau. 